\title{
MERGING GEOMETRIC DOCUMENTATION WITH MATERIALS CHARACTERIZATION AND ANALYSIS OF THE HISTORY OF THE HOLY AEDICULE IN THE CHURCH OF THE HOLY SEPULCHRE IN JERUSALEM
}

\author{
A. Georgopoulos ${ }^{1}$, E. Lambrou ${ }^{2}$, G. Pantazis ${ }^{2 *}$, P. Agrafiotis ${ }^{1}$, A. Papadaki ${ }^{1}$, L. Kotoula ${ }^{1}$, K. Lampropoulos ${ }^{3}$, E. Delegou ${ }^{3}$, \\ M. Apostolopoulou ${ }^{3}$, M. Alexakis ${ }^{3}$, A. Moropoulou ${ }^{4}$ \\ ${ }^{1}$ National Technical University of Athens, School of Rural and Surveying Engineering, \\ Laboratory of Photogrammetry \\ ${ }^{2}$ National Technical University of Athens, School of Rural and Surveying Engineering, \\ Laboratory of General Geodesy \\ gpanta@survey.ntua.gr \\ ${ }^{3}$ National Technical University of Athens, School of Chemical Engineering, \\ Laboratory of Materials Science and Engineering \\ ${ }^{4}$ Scientific Coordinator, NTUA Interdisciplinary Research Group for the protection of monuments \\ Zografou Campus, Heroon Polytechniou 9, 15780, Zografou, Athens, Greece
}

KEY WORDS: Geometric Documentation, Image based modelling, Terrestrial laser scanning, Non-destructive Techniques, Materials, Geomatics

\begin{abstract}
:
The National Technical University of Athens undertook the compilation of an "Integrated Diagnostic Research Project and Strategic Planning for Materials, Interventions Conservation and Rehabilitation of the Holy Aedicule of the Church of the Holy Sepulchre in Jerusalem". This paper focuses on the work merging the geometric documentation with the characterization of materials, the identification of building phases and the diagnosis of decay and pathology through the use of analytical and non-destructive techniques. Through this integrated approach, i.e. through the documentation and characterization of the building materials, through the diagnosis of decay and pathology, through the accurate geometric documentation of the building and through the non-destructive prospection of its internal structure, it was feasible to identify the construction phases of the Holy Aedicule, identifying the remnants of the preserved earlier constructions and the original monolithic Tomb. This work, thus, demonstrates that the adoption of an interdisciplinary approach for integrated documentation is a powerful tool for a better understanding of monuments, both in terms of its structural integrity, as well as in terms of its state of preservation, both prerequisites for effective rehabilitation.
\end{abstract}

\section{INTRODUCTION}

In May 2015, the National Technical University of Athens, after invitation from His All Holiness, Beatitude Patriarch of Jerusalem and All Palestine, Theophilos III, signed a programmatic agreement with the Jerusalem Patriarchate to compile and implement an "Integrated Diagnostic Research Project and Strategic Planning for Materials, Interventions Conservation and Rehabilitation of the Holy Aedicule of the Church of the Holy Sepulchre in Jerusalem". Within this framework an interdisciplinary Research Group was formed, consisting of Chemical Engineers, Geomatics and Surveying Engineers, Architects and Civil Engineers of NTUA. The interdisciplinary group undertook the task to conduct a thorough study of the existing situation of the Holy Aedicule and propose an integrated implementation of documentation, conservation, and structural supporting actions to enable the rehabilitation of the monument by March 2017.

In this paper, the works merging the geometric documentation with the characterization of materials, the identification of building phases and the diagnosis of decay and pathology through the use of analytical and non-destructive techniques are presented. This combined analysis elucidates the construction phases and the hidden historical information behind the contemporary structure, which significantly affects its current state of preservation and forms the basis for the development and implementation of the conservation, reinforcement and repair interventions that were scheduled and have been completed in time by March 2017.

\section{THE HOLY AEDICULE IN THE CHURCH OF THE HOLY SEPULCHRE}

The Church of the Anastassis (Resurrection) or of the Holy Sepulchre, as it is mostly known to western visitors, lies majestically in the heart of the Old City of Jerusalem, and has a very long history spanning over seventeen centuries (Figure 1). The first church in this site was erected by Saint Helen, the mother of Emperor Constantine the Great, when she discovered the Holy Cross at the beginning of the fourth century A.D. Since then, a lot of constructions, modifications, additions, renovations and alterations took place, the major one being that imposed by the crusaders in the $12^{\text {th }}$ century A.D. when they conquered the Holy Land.

The Church of the Holy Sepulchre in Jerusalem comprises within its walls, among others, the main large Greek Orthodox church, the Catholicon, the Holy Rock of Golgotha, the Tomb of Christ and the place where the Holy Cross was discovered. Adjacent to these main places of worship and pilgrimage are numerous little chapels, monk cells, store rooms, corridors and staircases, extending to approximately 8000 sq. metres in plan area and to about 35 metres of height difference. The main building complex has common borders with the Greek 
Orthodox Patriarchate, the Syrian Patriarchate, the Roman Catholic Monastery, the Ethiopian Monastery and a series of little souvenir stores.

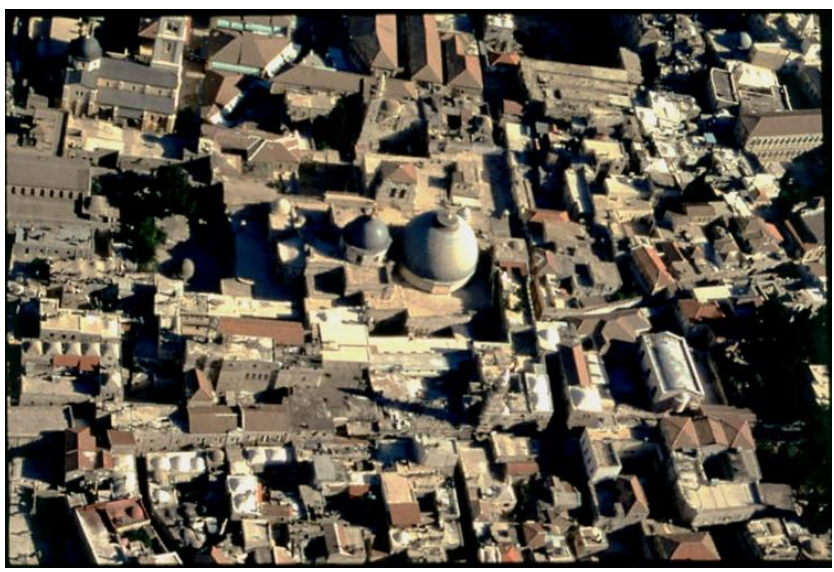

Figure 1: The Church of the Holy Sepulchre

Today the Church complex is a living monument and it is visited every year by thousands of pilgrims. All different Christian Communities are represented and active within its walls. Greek Orthodox, Roman Catholic Franciscan, Armenian and Coptic priests and monks and others are coexisting in harmony worshipping the same God. The monument is divided into sections each one "belonging" to a Community. There are, of course, sections of it common to everybody. All Christian Communities respect this unique state of ownerships while it is hardly sensed by the visitors. It constitutes the Status Quo of the Church of the Holy Sepulchre, which has its origins in historical tradition.

The Tomb of Christ is in the Church of the Holy Sepulchre in Jerusalem. The original Holy Rock is covered by the Holy Aedicule, a majestic little structure situated within the large complex of the Church of the Holy Sepulchre in the centre of the Rotunda, a 25m tall cylindrical building. The Holy Aedicule is the latest in a series of constructions and additions to the initial Crusader Aedicule which had occupied the same site for centuries (Biddle 1999). Responsible for the design and reconstruction of this latter one was the architect Komnenos in the early 19th century. The present form of the Holy Aedicule, which exists without significant alterations since 1810 , is a result of repair and restoration of the earlier building after the catastrophic fire of 1808 . It has approximately a length of $8.3 \mathrm{~m}$, a width of $5.5 \mathrm{~m}$, and a height of $6.7 \mathrm{~m}$ plus a dome of $6.0 \mathrm{~m}$ on its roof.

The exact form of the earlier buildings, also a result of a restoration of an even earlier form, which is closer to the initial form surrounding the Holy Rock, appears in 1609 drawings together with a brief description, a citation on the dimensions and explanatory notes (Bernardino, 1920). It was formed like that by the Crusaders during their occupations of the Holy Land in the $11^{\text {th }}$ and $12^{\text {th }}$ centuries.

In 1927, this construction was badly damaged by an earthquake which also weakened the dome over the Rotunda and other parts of the complex. Marble slabs cover the outside surface of the Aedicule, while it is also surrounded by a metallic construction (Figure 2) erected by the British in 1947 which provides support and stops the collapse of the Holy Aedicule. Timber wedges were inserted between the steel girders and the load-bearing stone walls of the Holy Aedicule. It appears that this steel girdle is no longer functional, as lately deformations were observed especially as far as the Komnenos' marble slabs are concerned. The inside the Holy Aedicule is a complex structure with two very confined, highly ornamented rooms.

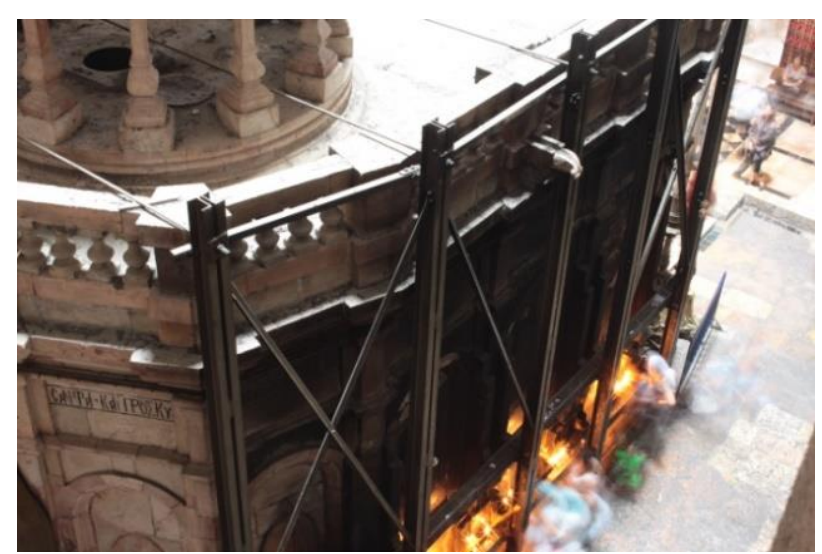

Figure 2: The south façade of the Holy Aedicule in 2015

However, the state of preservation of the Holy Aedicule continued to deteriorate due to the water and humidity transfer phenomena within, around and below the Aedicule structure, due to incompatible past interventions and due to the successive earthquake activity, to the extent that proper conservation, reinforcement and repair interventions were needed to rehabilitate the Holy Aedicule. The first task of the interdisciplinary team of NTUA was to perform the geometric documentation of the Holy Aedicule, as foreseen in the Venice Charter (article 16). This documentation was, of course, part of a wider range of technical studies of the interdisciplinary team of NTUA engineering experts.

\section{GEOMETRIC DOCUMENTATION OF THE HOLY AEDICULE}

\subsection{Previous Documentation Efforts}

In the past, several efforts for the geometric documentation of the Church of the Holy Sepulchre and the Holy Aedicule in it took place. Already since the 60's the Franciscan monk Corbo, documented, mainly as an archaeologist, a large part of the Church using of course the then available technological means (Corbo, 1981). Later (Biddle 1992) a team of British experts documented in high detail the Holy Aedicule. In the years 19931999, the Laboratories of General Geodesy and of Photogrammetry of NTUA undertook and executed (Figure 3) the complete geometric documentation at a scale of 1:50 of the Church of the Holy Sepulchre for the Greek Orthodox Patriarchate (Balodimos et al. 2003, Georgopoulos \& Modatsos 2002, Lavvas 2009). Finally, in the years 2007-2009 a team of Italian experts embarked on terrestrial laser scanning for the complete 3D documentation of the Church (Tucci \& Bonora 2011).

\subsection{Data acquisition}

For the current geometric documentation of the Holy Aedicule before the restoration works, several campaigns were necessary. The first one took place in May 2015 (Moropoulou et al. 2015) and the second one in January 2016. Data acquisition included geodetic measurements, digital image acquisition and terrestrial laser scanning around and inside the Holy Aedicule. 


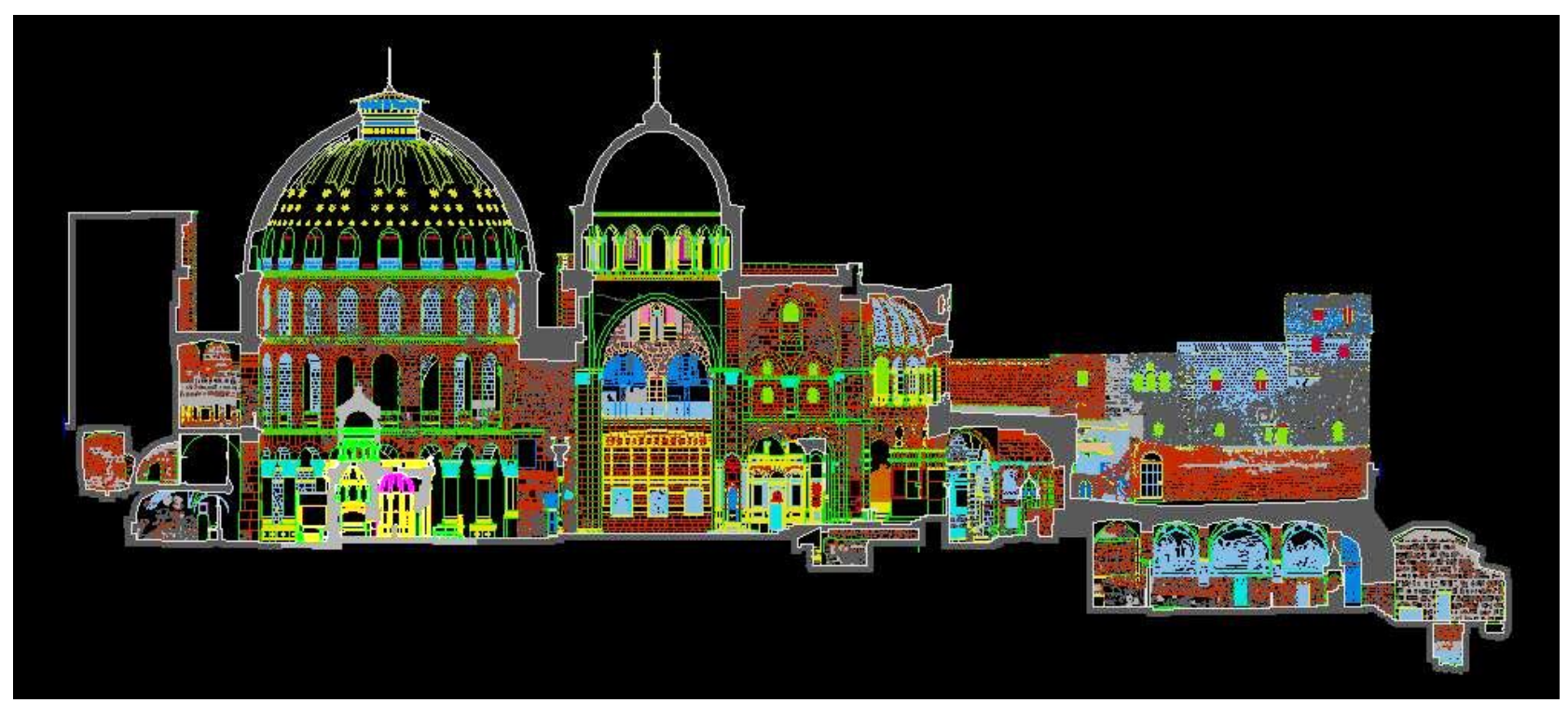

Figure 3: Sample of the geometric documentation 1993-1999

This present geometric documentation aims at the production of the necessary base material on which the structural and material prospection studies will be based. For the needs of this documentation it was decided to produce a high resolution three-dimensional model and to perform specialized high accurate geodetic measurements for the production of conventional 2D base material on one hand and for the documentation of the deformations and deviations of the construction today on the other. Due to the peculiarities of the object of interest, the crowds of pilgrims always present inside and around the Aedicule, most of the works for the data acquisition took place after the closure of the Church. The methodology implemented for the production of the above described products applied the most contemporary geomatics techniques and specialized instrumentation. Briefly, an automated 3D imaging methodology based on high resolution digital images, terrestrial laser scanning and high accuracy geodetic measurements were implemented. These data were georeferenced to an already existing local plane projection reference system from previous work of NTUA (Balodimos et al. 2003).

Specifically, the geometric documentation produced an accurate three-dimensional (3D) model with the use of photogrammetric and geodetic methods, both for the interior and the exterior of the Holy Aedicule through images and scanned data collection for the reconstruction of the model in actual scale. This was realized via data processing (sorting of images, orientation, export 3D cloud points, dense point cloud processing, creation of surfaces and grouping them), for reconstructing 3D scenes of increased reliability and high accuracy. From this 3D model the production of sections at specific positions was also possible, supported by suitable geodetic measurements.

\subsection{Image based modelling}

For the image based approach, digital image sequences from varying distances were collected using a calibrated professional Canon EOS-1Ds Mark III full frame CMOS digital camera with $21 \mathrm{MP}$ resolution $(5616 \times 3744$ pixels $)$ and $6.4 \mu \mathrm{m}$ pixel size, aiming to reconstruct the 3D scene of the Holy Aedicule through structure from motion (SfM) and Dense Image Matching (DIM) techniques. These techniques are the state of the art in reconstructing 3D scenes and offer high reliability and high accuracy as a cost and time effective alternative to the use of scanners. For this purpose, different lenses with a varying focal length $(16 \mathrm{~mm}, 50 \mathrm{~mm}, 135 \mathrm{~mm}$ and $300 \mathrm{~mm})$ were used. The image acquisition took place under low natural lighting conditions and during the night, exploiting the existing artificial lighting. No additional light sources were used (flash, studio flash, etc.). Therefore, the use of a photographic tripod was necessary since in some cases, the exposure time was up to 30 seconds. 3.757 images in total were captured requiring up to 59.3GB of hard drive space. However, a selection process was applied in order to ensure a highly accurate result according to the requirements of the study and the significance of the object. Finally, distances were accurately measured on the Holy Aedicule in order to scale the final 3D model. Problems in the acquisition processes such as lighting conditions and camera-toobject relative positioning as well as difficulties in the alignment step and mesh optimization are also encountered without reducing the accuracy of the final results. These problems included, among others, the large distances between the object and the camera, the poor or inadequate lighting, the continuous population of the area by pilgrims, the smoke from the candles, which create faded areas on the images or unpredictable optical deformations due to the refraction effect caused by the temperature difference of the air.

\subsection{Terrestrial Laser Scanning}

In addition, laser scanning was also employed, in order to cover the areas where image acquisition was impossible, like e.g. the dark and smoked interiors of the two domes of the Holy Aedicule and the two staircases leading to the construction's roof. The two techniques act complementarily to each other. For this procedure the terrestrial laser scanner FARO 3D X 330 was chosen as it is a lightweight third generation scanner, which uses the phase shift method for measuring the distance. It has the ability of collecting one million points per second with an accuracy of 2-3 $\mathrm{mm}$ in its space position. It can record points 360 degrees around the vertical axis and 300 degrees around the horizontal axis. For the complete coverage of the Holy Aedicule special scanning strategy was designed, in order to avoid gaps in the point clouds on one hand and to record all necessary details on the other. For that purpose, it was necessary to 
acquire overlapping scans from different scan positions. In total 58 scans were needed, of which 13 around the Holy Aedicule, 8 on top of its roof, 8 in the two staircases, 10 from the Rotunda Gallery and 19 in the inside. The total number of points collected was 65 million for the outside and 42 million for the inside.

The density of the scans was selected to 1 point every $5 \mathrm{~mm}$, in order to record all fine details, even those necessary at a later stage. The time required for each scan varied depending on the distance of the scanner to the object, a fact which differentiates the total number of points necessary. In any case the time for each scan was not more than a few minutes.

\subsection{Data Processing and Results}

The creation of the final accurate three-dimensional model from the digital images is a complicated procedure requiring large computation cost and human effort. It includes the already mentioned collection of geometric data in limited space and time, the selection of the images, the $3 \mathrm{D}$ point cloud extraction, the creation of the surface, the noise filtering and the merging of individual surfaces. It is important to note that in such cases, the detail of the surface is very important, thus the noise filtering must be a carefully implemented procedure. The initial data were processed using various software packages in order to produce the final accurate 3D model of the Holy Aedicule. In the diagramme of Fig. 4 the flowchart designed and adopted for the initial data processing procedure (images and measurements) is presented. After the careful selection of the necessary images and the creation of thematic folders, the radiometric correction of the imagery took place aiming at their quality improvement by minimizing the effects of the shadows and dark areas. Then, the images are imported into the software that implements SfM and DIM techniques. Subsequently, the dense point cloud is exported and imported to another software package in order to be subjected to a time-consuming process for removing outliers.

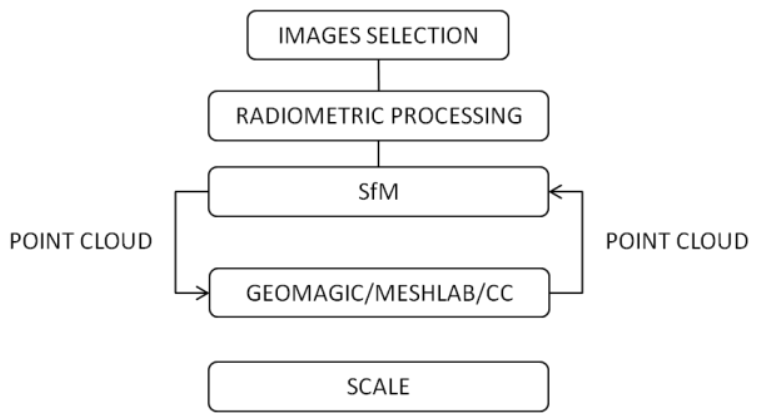

Figure 4: Data processing workflow

Finally, the processed point clouds are merged and exported again in order to be scaled. The SfM technique for the orientation of the images and the $3 \mathrm{D}$ point cloud extraction procedure were realized through the use of Agisoft's PhotoScan ${ }^{\circledR}$ software, which has been extensively evaluated for increased accuracy in prior research internationally but also of the Laboratory of Photogrammetry (Georgopoulos, 2015).

For the full coverage of the Holy Aedicule and the creation of a complete 3D model, images were captured from many different locations. It is important to note that for every part of the 3D model, the sparse point clouds consist of 10.000 to 60.000 points. After an inspection of the alignment results, the generation of the dense point cloud model took place. At this stage, the Agisoft PhotoScan ${ }^{\circledR}$ algorithms, based on the estimated camera positions calculate depth information for each camera to be combined into a single dense point cloud. It is noted that the dense point cloud of each part of the 3D model of the Holy Aedicule consists of about 35.000 .000 points and the entire model of about 280.000 .000 points (Fig. 5). At this stage, color is attributed to each point based on the images where it appears. In the outside coloured point cloud of the Holy Aedicule is presented.

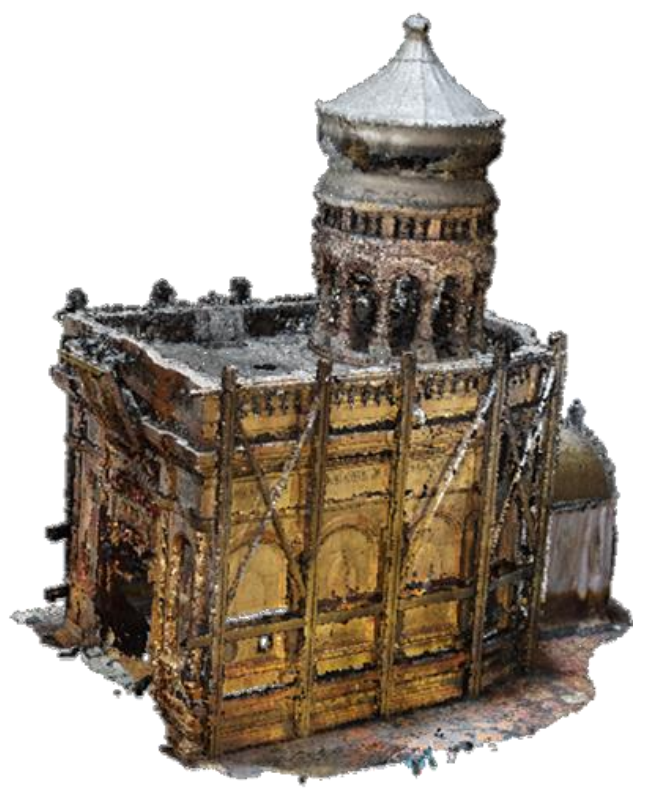

Figure 5: The coloured point cloud of the Holy Aedicule

The processing of the Holy Aedicule point cloud was realized within the Geomagic Studio ${ }^{\circ}$, Meshlab ${ }^{\circledR}$ and Cloud Compare ${ }^{\circledR}$ software. Also to sort out the outliers, several filtering algorithms are applied using the above mentioned software packages. In addition, algorithms were applied in order to make the point cloud uniform in terms of point spacing and reduce its density. Finally, the processed dense point clouds are wrapped into meshes. Figure 6 presents the part of the 3D model of the dome, which is one of the more complex parts of the Holy Aedicule. Through the created 3D model, it is possible to identify vulnerable and destroyed areas of the Holy Aedicule with not physical access on them.

The laser scanner data were thoroughly examined for their completeness in situ, i.e. before the departure of the team from Jerusalem. For that purpose, test registrations of the point clouds were performed in order to establish this possibility on one hand and their completeness on the other. After these tests, additional scans were required sometimes from very unconventional scan positions.

The final point cloud registration was performed in the Laboratory of Photogrammetry of NTUA. As the volume of data was huge it was decided to perform the registration separately for the inside and outside parts of the Holy Aedicule. For the point cloud registration, at least three points are required. This role was undertaken by the special targets, whose coordinates in the common reference system were carefully determined. Hence after registration the point clouds were also referenced to the common system. The accuracy achieved for the registrations was of the order of $2-3 \mathrm{~mm}$. In Figure 7 a sample of the registered point clouds is shown. 

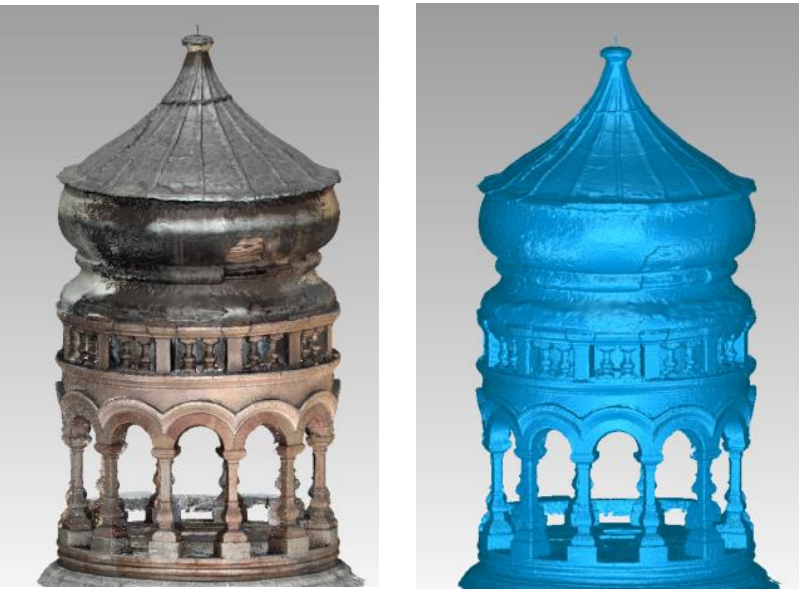

Figure 6: The 3D model of the dome textured (left) and nontextured (right)

For registering and georeferencing the three-dimensional models of the Holy Aedicule which were produced with the methods described to the common reference system, specially targeted points were put in suitable positions on inside and outside of the Holy Aedicule but also in the surrounding area. In total 38 control points were used.

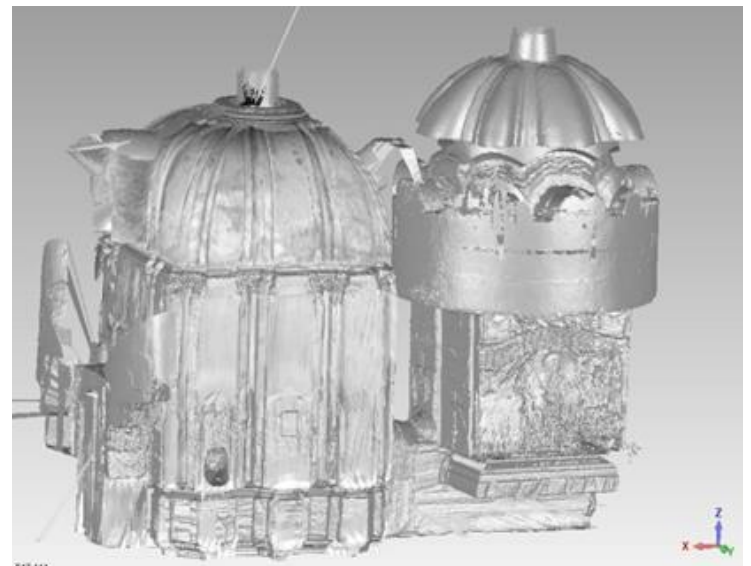

Figure 7: Part of the registered point clouds inside the Holy Aedicule

\subsection{Deformation measurements}

Accurate geodetic measurements were performed in order to assess the verticality of structural elements, like the iron girder set up by the British in 1947 and some of the pillars of the monument. For that purpose, a local 3D network was established at the site around of the Holy Aedicule in order to support the creation of the 3D model of the Holy Aedicule and to determine probable deformations and displacements of the monument. The above mentioned geodetic network connected with the old geodetic network which had been established the period 1993-1999, in the framework of the Geometric an Architectural Documentation of the Church of the Holy Sepulchre in Jerusalem (Balodimos et al. 2003).

For checking the eventual deviations and deformations of the structural elements several measurements were performed. A longitudinal section of the upper dome of the structure, four horizontal sections of the same dome at $6.0 \mathrm{~m}, 8.0 \mathrm{~m}, 8.8 \mathrm{~m}$ and $12.0 \mathrm{~m}$ from the floor, two horizontal sections of the pillars and the marble supports of the Aedicule at $0.7 \mathrm{~m}$ and $4.4 \mathrm{~m}$ from the floor. In addition, special accurate measurements were conducted in order to establish the deviation from the vertical of the steel pillars of the cage built by the British.

Moreover, the change of the position of each the five basic columns at the north façade and the counterpart columns at the south façade of the Holy Aedicule, is determined from the corresponding position that the British as registered in 1947. These measurements led to the important conclusion that the upper dome of the structure does not present any significant deformations, as all sections were concentric circles within $7 \mathrm{~mm}$ (Figure 8). This was also established by examining the longitudinal section of dome.

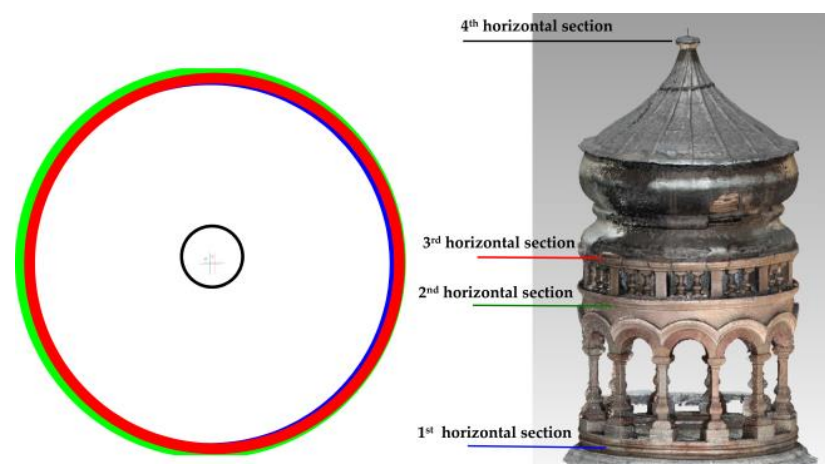

Figure 8: The horizontal sections of the upper dome of the Holy Aedicule

The horizontal sections of the pillars revealed deviations between 40 and $90 \mathrm{~mm}$. These results were also verified from the 3D model produced. The measurements on the vertical steel girder pillars, revealed severe deformations both in the vertical plane as well as in the horizontal, i.e. significant bending about 23 " from the plumb line (Figure 9).

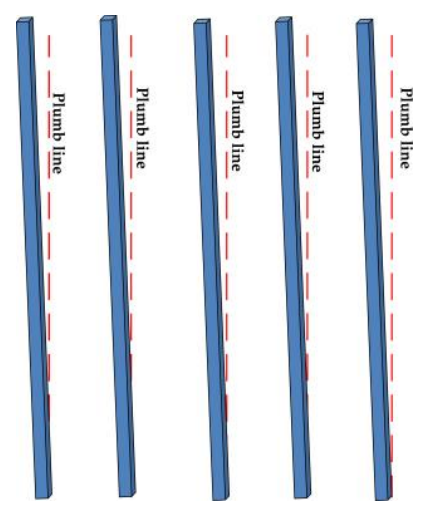

Figure 9: Deformations of the steel pillars

Finally, in Figure 10 the change of the declination of each part of the Holy Aedicule's columns during the last seventy years is presented.

\section{CHARACTERIZATION OF THE HOLY AEDICULE'S BUILDING MATERIALS}

As part of an integrated methodology for the diagnosis of decay and the pathology, the building materials of the Holy Aedicule were documented and their characterization composition, provenance, morphology and physicomechanical properties were characterized, through an array of complementary analytical and non-destructive techniques such as thermal analysis, microstructural analysis (scanning electron 
microscopy, polarized microscopy, porosimetry, etc.), digital portable microscopy, pulse-echo tomography, colorimetry, and others. In addition, infra-red thermography provided crucial information about the state of preservation of the examined surfaces and allowed the identification of the prevailing decay phenomena.

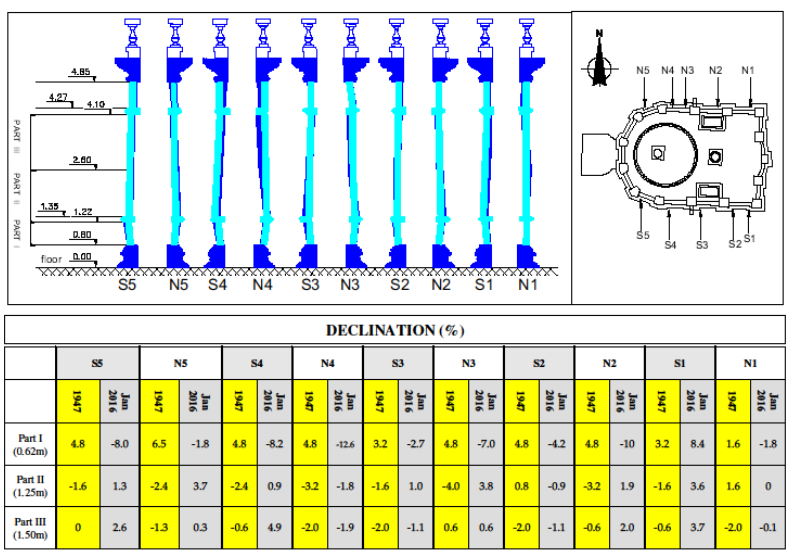

Figure 10: The change of the declination of the Holy Aedicule's columns

The study conducted regarding the documentation and characterization as well as the diagnosis of the decay of the Holy Aedicule historical masonry mortars (Fig. 11), identified the mortars as lime mortars with a slight hydraulic character attributed to the presence of CAH (hydrated calcium aluminate salts) which develop during the setting and hardening process of hydraulic lime produced from the calcination of marly limestones.
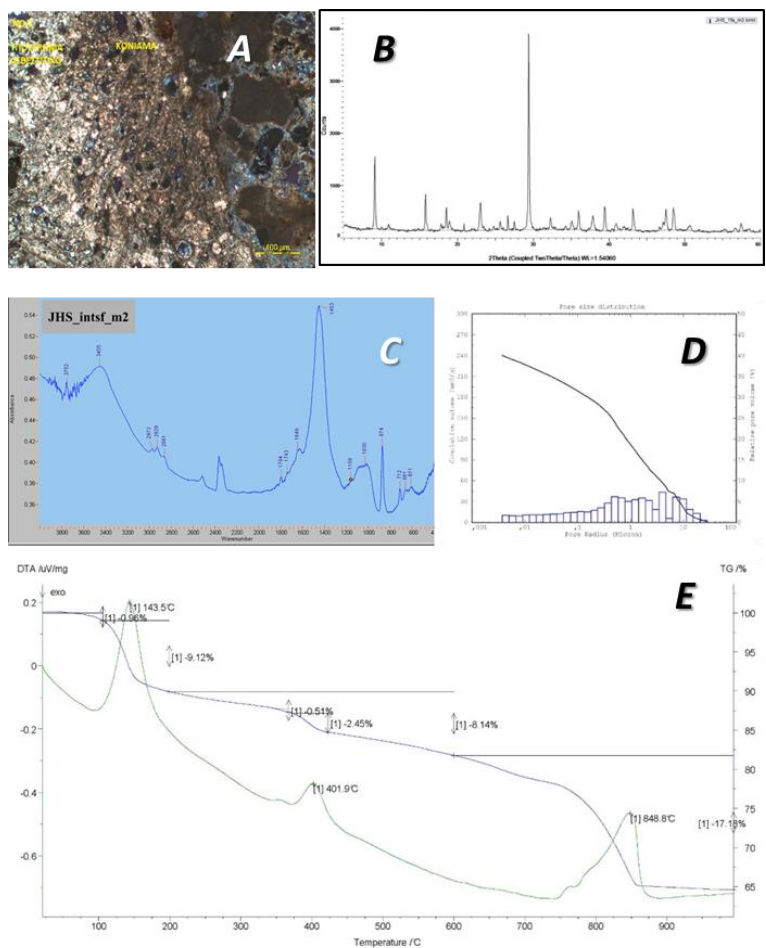

Figure 11: Typical results from the characterization study of historic mortars: A) Polarized Microscopy; B) X-Ray Diffraction (M3 mortar); C) Fourier Transform Infrared Spectroscopy (M2 mortar); D) Pore-size distribution curve (M1 mortar); E) Thermal Analysis DTA/TG (M3 mortar)
A high percentage of soluble salts was detected in the historical mortars samples, which is a crucial parameter leading to the deterioration of the structural materials. The presence of salts is the main cause leading to the mortar deterioration, in combination with the inflow of water through the dome opening (in the past), rising damp and humidity condensation. The original mortar aggregates consisted of a mixture of sands or a mixture of sand and crushed brick aggregates, with the sporadic presence of hay straw or white fibers. The mortars were in a bad state of preservation and have lost their serviceability. Three general categories of mortars were identified: M1: a lime mortar belonging to the Komnenos construction phase, which was identified by polarized microscopy as microcystalline calcite with ferrous oxides-hydroxides in binder phase and aggregates consisting of crushed brick ( $<10 \%$ of mortar), recrystallized quartz $(<4 \%)$, and fragments of limenstone composition $(<$ 15\%); M2: a lime mortar mainly of calcitic composition with aggregates consisting of fragments of micritic limestone consisting of calcite, quartz fragments $(<2 \%)$, serpentine fragments, mineral apatite syndromes $(<3 \%)$, chlorite and mica (muscovite composition); M3: a lime mortar of microcystalline calcite, with aggregates consisting of larnite minerals $(<6 \%)$, gypsum $(\sim 5 \%)$ and quartz $(<7 \%)$. In M2 and M3 mortars, ettringite was detected, which is, however, common in veins and cavities of Israel's Hatrurim rock formation and it is produced from the crust corrosion of larnitic rocks.

Building stones of the Holy Aedicule were characterized. The external façade building stone is a micritic fossiliferous limestone of a micritic calcite main phase, with secondary phases including quartz crystals, clay minerals, opaque metallic minerals and oxides and hydroxides of Fe. It has a $0.32 \%$ total porosity, $0.39 \mathrm{~m}^{2} / \mathrm{g}$ specific surface, $77.8 \mathrm{MPa}$ yield strength, $38.2 \mathrm{GPa}$ Young's modulus. The interior masonry building stone corresponding to the Crusaders construction phase is a limestone of a micritic and microsparitic calcite main phase, with secondary including quartz crystals and oxides and hydroxides of $\mathrm{Fe}$. It has $18.33 \%$ total porosity, $0.11 \mathrm{~m}^{2} / \mathrm{g}$ specific surface, $12 \mathrm{MPa}$ yield strength and 0.8GPa Young's modulus. The building stone from at the internal staircase which corresponds to the Komnenos' construction phase is a microcrystallic dolomite with secondary phases including calcite, quartz and alite crystals, $15.82 \%$ total porosity and $0.14 \mathrm{~m} 2 / \mathrm{g}$ specific surface. The Holy Rock is a micritic limestone of micritic calcite main phase, with secondary phases including opaque metallic minerals and oxides of $\mathrm{Fe}, 22.36 \%$ total porosity, $0.26 \mathrm{~m}^{2} / \mathrm{g}$ specific surface, $10.3 \mathrm{MPa}$ yield strength, 21.7GPa Young's modulus.

\subsection{Assessment of incompatibility of historic building materials of the Holy Aedicule}

Infra-red thermography (IRT) was utilized to assess the physicochemical incompatibility between the historic filler mortar and the building stone of the internal masonry of the Holy Aedicule. Figure 12 shows the results of IRT on a typical façade core sample. Due to its erosion, mortar performativity has been lost, attributing lower temperatures than the building stone within a temperature range of $3^{\circ} \mathrm{C}$, whereas the $1^{\circ} \mathrm{C}$ temperature range indicates the moisture transportation procedure from the rich ettringite lime mortar JHS_fa_m2 (M2 mortar) to the building stone JHS_1fa_ws (Crusader's construction phase) and lime mortar JHS_fa_m1 (M1 mortar). The thermal heterogeneity of the building materials of the Holy Aedicule, at the scale of the monument, is highlighted in Figure 13. 




JHS_fa_m2

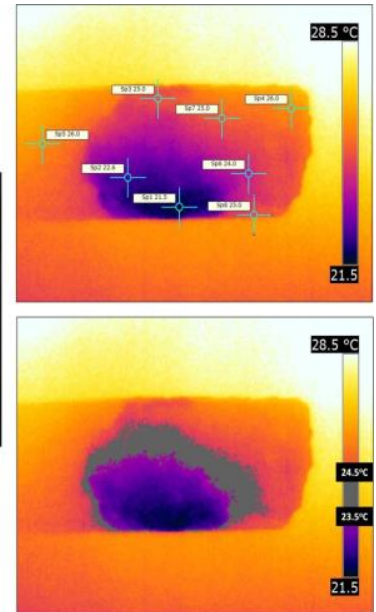

Figure 12: Assessment of physicochemical incompatibility between the joint mortars and the stone, as assessed by infrared thermography

The thermographic examination of the north façade of the Holy Aedicule revealed that the temperature distribution differentiates according to the various building stones of the façade, combined with the distribution and the concentration of black deposits from dust and smoke particles of burning candles and oil-lamps. A higher temperature by $1.5^{\circ} \mathrm{C}$ is observed for the building stones neighbouring the flame of the candles. The anisotropic heat distribution over the surface of the façade stones and subsequently in the deeper layers of the structure via the mechanism of heat induction, and the maintenance of that temperature difference at least by $0.5{ }^{\circ} \mathrm{C}, 3$ hours after burning the candles out, indicates a significant local thermal heterogeneity which is attributed to the incompatibility of the building materials of the successive construction phases of the Holy Aedicule. The aforementioned action, taking place in a daily basis causes corresponding changes in the thermohygrometric behaviour of the building materials of the masonry, accelerating their deterioration.
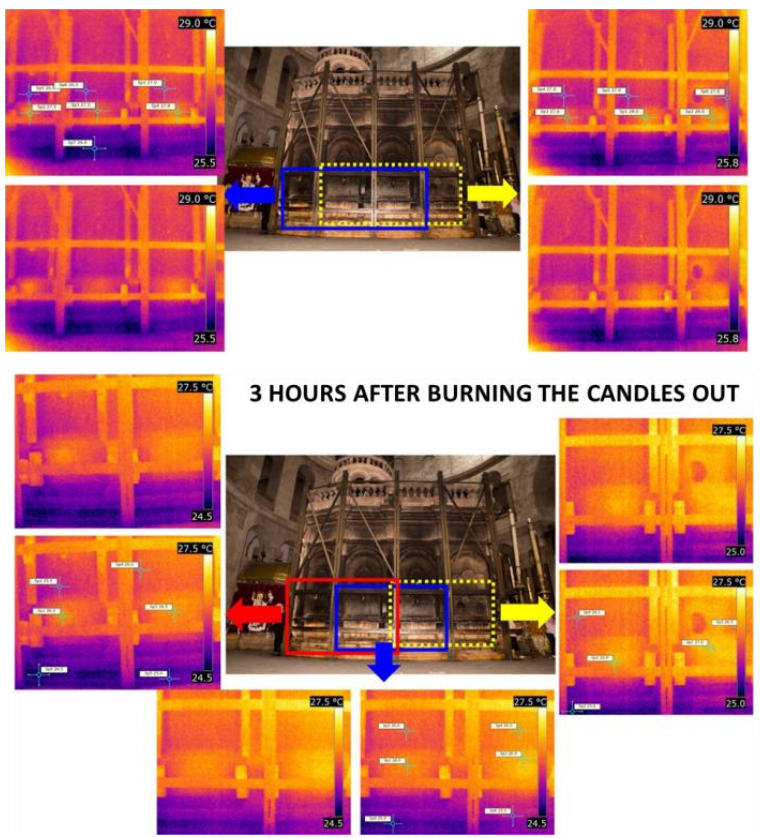

Figure 13: Thermal heterogeneity of the building materials of the Holy Aedicule, at the scale of the monument, assessed by IRT, regarding the effect of candles burning close to the external surfaces

\section{PROSPECTION OF THE INTERNAL STRUCTURE OF THE HOLY AEDICULE}

In order to allow effective correlation of the results from the materials analysis with the 3D model of the Holy Aedicule, a prospection of its internal structure was accomplished by an extensive survey with ground penetrating radar (GPR). Through this technique, and by utilizing information from historic documentation and architectural analyses, it was feasible to reveal the construction phases of the Holy Aedicule. Figure 14 summarizes the results of the GPR prospection, revealing the internal layers. Specifically, from the outside towards the interior of the structure, the following layers are revealed. Externally, $10-15 \mathrm{~cm}$ thick façade stones cover the main Aedicule structure. Immediately behind the façade stones, there exists a layer of a filler mortar, with a thickness of $5-20 \mathrm{~cm}$ depending on the area. This mortar fills the gap between the internal surface of the façade stone layer and the outer surface of the main internal masonry. At the western part of the Holy Aedicule, there exist - embedded within the main masonry - the remnants of the Monolithic Holy Aedicule, in the form of two blocks of Rock, including the Arcosolium at the north block, approximately $2 \mathrm{~m}$ higher than the level of the interior floor of the Holy Aedicule. The shape of these rock blocks has been determined by GPR by successive heightwise prospections throughout the Holy Aedicule, which allowed for the identification of the outlines of the rock blocks per height. These 2D horizontal sections of the GPR scans, containing the digitized outlines of the Holy Rock blocks, were then georeferenced using the 3D model of the Aedicule structure, placed according to their elevation.

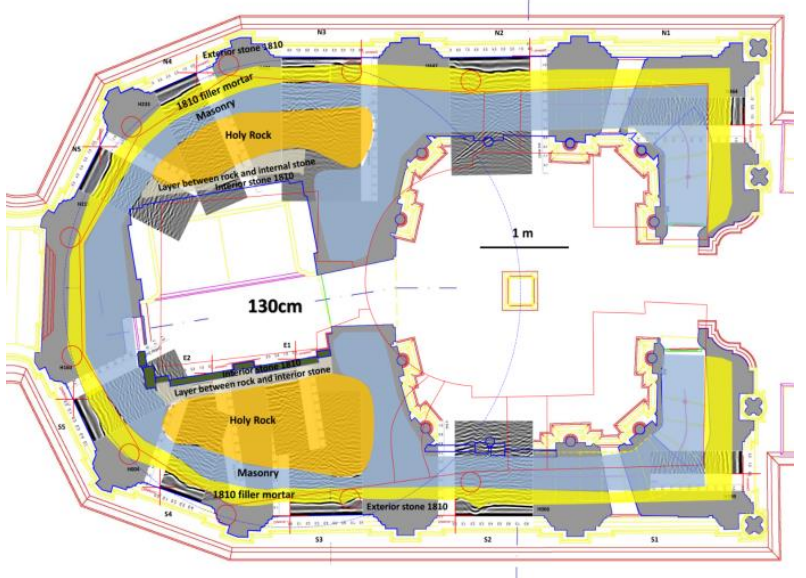

Figure 14: Plan (at $130 \mathrm{~cm}$ height relative to the interior floor level) indicating the results from the prospection analysis of the internal structure of the Holy Aedicule with ground penetrating radar at its surfaces. Yellow zone corresponds to the filler mortar. Blue zone corresponds to the main masonry. Orange areas corresponds to the two rock blocks (north and south respectively), which correspond to the remnants of the original monolithic Holy Aedicule.

\section{CONCLUSIONS}

The geometric documentation carried out produced a 3-D high resolution model, through the combination of automated image based method and using terrestrial laser scanning. Using the final model, it was possible (i) to extract the eventually necessary conventional two dimensional products, such as e.g. horizontal and vertical sections, facades etc., (ii) to produce suitable visualizations for the support and design of the 
restoration interventions and (iii) to virtually visualize the internal structure of the Holy Aedicule in three dimensions. Through this integrated approach, i.e. through the documentation and characterization of the building materials, through the diagnosis of decay and pathology, through the accurate geometric documentation of the building and through the non-destructive prospection of its internal structure, it was feasible to identify the construction phases of the Holy Aedicule, identifying the remnants of the preserved earlier constructions and the original monolithic Tomb.

The geometric documentation products helped to carefully plan the interventions and compile the "Integrated Diagnostic Research Project and Strategic Planning for Materials, Interventions Conservation and Rehabilitation of the Holy Aedicule of the Church of the Holy Sepulchre in Jerusalem". In particular, the remnants of the monolithic original Aedicule were identified, embedded within the main body of the current Aedicule. 2D horizontal sections of the GPR scans, containing the digitized outlines of the Holy Rock blocks, were georeferenced using the 3D model of the Aedicule structure, placed according to their elevation. Based on this, a 3D visualization of the GPR data was accomplished incorporated to the existing high resolution 3D model of the interior of the Holy Aedicule (Agrafiotis et al. 2017). As already presented, the building materials of the Holy Aedicule were documented, were characterized, and georeferenced according to the geometric documentation products.

Within this scientific work of studying and analysing the current situation of the Holy Aedicule a methodology was employed to construct the 3D model of the rock and introduce it into the 3D model of the whole building, thus enhancing the information about the structure. This work, thus, demonstrated that adopting an interdisciplinary approach for documentation can emerge as a powerful tool for a better understanding of monuments, both in terms of its structural integrity, as well as in terms of its state of preservation, both prerequisites for effective rehabilitation.

\section{ACKNOWLEDGEMENTS}

The project became possible and is executed under the governance of His Beautitude Theophilos III, Patriarch of Jerusalem. The Common Agreement of the Status Quo Christian Communities responsible for the Holy Sepulchre provides the statutory framework for the execution of the project.

His Paternity the Franciscan Custos of the Holy Land, Rev. f. Pierrebattista Pizzaballa, and His Beatitude the Armenian Patriarch in Jerusalem, Nourhan Manougian, that authorized His Beatitude the Patriarch of Jerusalem Theophilus III and NTUA to perform this research. Contributions from entities and persons all over the world secure the project's funding. Worth noting Mica Ertegun's donation through WMF, Aegean Airlines et al. Additionally, for the 3D models of the Aedicule presented here, the contribution of Prof. Ch. Ioannidis, S. Soile and S. Tapinaki, members of the Geometric Documentation team is gratefully acknowledged.

\section{REFERENCES}

Agrafiotis, P., Lampropoulos, K., Georgopoulos, A., Moropoulou, A. 2017. 3D Modelling the Invisible using Ground Penetrating Radar. Int. Arch. Photogramm. Remote Sens. Spatial Inf. Sci., XLII-2-W3, 33-37, TC II \& CIPA 3D Virtual Reconstruction and Visualization of Complex Architectures 1-3
March 2017, Nafplio, Greece Editor(s): D. Aguilera, A. Georgopoulos, T. Kersten, F. Remondino, and E. Stathopoulou

Balodimos, D., Lavvas G., Georgopoulos, A., 2003. Wholly Documenting Holy Monuments CIPA XIX International Symposium, 2003, Antalya.

Bernardino Amico da Gallipoli, 1920. Trattato delle piante et imagini dei sacri edificii di Terrasanta, Rome 1609 and Florence.

Biddle, M., 1999. The Tomb of Christ. Sutton Publishing Ltd., ISBN 0-7509-1926-4, 173pp.

Biddle, M., Cooper, M.A.R., Robson, S., 1992. The Tomb of Christ, Jerusalem: a photogrammetric survey, The Photogrammetric Record, 14(79), 25-43.

Binda, L., Lenzi, G., \& Saisi, A., 1998. NDE of masonry structures: use of radar tests for the characterisation of stone masonries. NDT \& E International. 1998; 31(6): 411-419

Binda, L., Saisi, A., \& Tiraboschi, C., 2000. Investigation procedures for the diagnosis of historic masonries. Construction and Building Materials. 2000; 14: 199-233

Corbo, V.C., 1981. Il Santo Sepolchro di Gerusalemme. 3 vols. Publication of the Studium Biblicum Franciscanum 29, Jerusalem.

Georgopoulos, A., Modatsos, M., 2002. Non-metric bird's eye view. International Archives of Photogrammetry and Remote Sensing, 34(5), 359-362, Corfu, Greece.

Georgopoulos, A., 2015. Photogrammetric Automation: Is it Worth? Mediterranean Archaeology and Archaeometry, Vol. 16, No 5 (2016), pp. 11-17. 2nd International Symposium on Virtual Archaeology Museums and Cultural Tourism (September 2016 - Delphi, Greece) DOI: 10.5281/zenodo.204962.

Labropoulos, K., Moropoulou, A. 2013. Ground penetrating radar investigation of the bell tower of the church of the Holy Sepulchre. Construction and Building Materials. 2013; 47, 689700

Lavvas, G., 2009. The Church of the Holy Sepulchre in Jerusalem, Academy of Athens, 2009, 192 p., ISBN 978-960404-139-8 (in Greek).

Moropoulou, A., Labropoulos, K.C., Delegou, E.T., Karoglou, M., \& Bakolas, A., 2013. Non-Destructive Techniques as a tool for the protection of Built Cultural Heritage. Construction and Building Materials. 2013; 48: 1222-1239

Moropoulou A. I., Labropoulos K.C., 2015. "Non-Destructive Testing for Assessing Structural Damage and Interventions Effectiveness for Built Cultural Heritage Protection", in: P.G. Asteris, V. Plevris (Eds.), Handbook of Research on Seismic Assessment and Rehabilitation of Historic Structures, IGIGlobal, Hershey, PA, USA. 2015; 448-499.

Moropoulou, A., Korres, E., Georgopoulos, A., Spyrakos, C., 2015. Integrated Diagnostic Research Project and Strategic Planning for Materials, Interventions, Conservation and Rehabilitation of the Holy Edicule of the Holy Sepulchre in the Holy Church of the Resurrection in Jerusalem. Interim report (unpublished).

Moropoulou, A., Scientific Responsible 2016 "Integrated Diagnostic Research Project and Strategic Planning for Materials, Interventions Conservation and Rehabilitation of the Holy Aedicule of the Church of the Holy Sepulchre in Jerusalem", National technical University of Athens.

Tucci, G., Bonora , V., 2011. Geomatic techniques and 3D modeling for the survey of The church of the Holy Sepulchre in Jerusalem. Proceedings XXIII CIPA Symposium - Prague, Czech Republic - 12/16 September 2011. 